九州大学学術情報リポジトリ

Kyushu University Institutional Repository

\title{
On Some Jurassic Ammonites from Muktinath, in Nepal
}

Matsumoto, Tatsuro

Faculty of Science, Kyushu University

Sakai, Harutaka

Faculty of Science, Kyushu University

https://doi.org/10.5109/1546084

出版情報：九州大學理學部紀要：Series D, Geology. 25 (1)，pp.75-91，1983-11-15. Faculty of Science, Kyushu University バージョン :

権利関係 : 
Mem. Fac. Sci., Kyushu Univ., Ser. D, Geol., Vol. XXV, No. 1, pp. 75-91, text-figs. 1-4, plates 7-10, November 15, 1983

\title{
On Some Jurassic Ammonites from Muktinath, Nepal
}

\author{
Tatsuro MATSUMOTO* and Harutaka SAKAI
}

\begin{abstract}
One of us (H. S.) collected fossil cephalopods from a locality $3 \mathrm{~km} \mathrm{NWW}$ of Muktinath (Figs. 1, 2). They were in pyrite-bearing siliceous nodules derived from the black shale, a part of the Spiti Shales. Some of them were brought to the other of us (T. M.) for identification and the following six ammonites, which have been donated to Kyushu University, are described in this paper with illustrations (pls. 7-10): (1) Aspidoceras andinum STEUER, (2) Corongoceras lotenoense SPATH, (3) Virgatosphinctes aberrans sp. nov. (holotype), (4) Grayiceras blanfordi Spath, (5) Paraboliceras fascicostatum (UHLIG) and (6) Paraboliceras tibeticum (UhLIG). In addition to them, the specimens which were identified preliminarily to the following species were donated to Tribhuvan University: (7) Uhlgites cf. kraffti (UHLIG), (8) Kossmatia ef. desmidoptycha (UHLIG), (9) Kossmatia sp. aff. K. desmidoptycha (UHLIG) (microconch with lappets), (10) Virgatosphinctes sp. aff. V. broilii (UHLIG), ( $\left.3^{\prime}\right) V$. aberrans (paratype) and a number of belemnites. The faunule as a whole is of Tithonian age and most probably represents the Middle Tithonian, although a few species may suggest the upper Lower Tithonian or the lower Upper Tithonian. Finally palaeogeographic implications of the Spiti Shales and the faunas are discussed in the light of modern earth-sciences.
\end{abstract}

\section{Introduction}

One of us (H. S.) was working at the Department of Geology, Tribhuvan University, Nepal, as a member of Overseas Cooperation Volunteers from Japan for three years from 1980 to 1982 . When he made a geologic reconnaissance in the area northwest of Mt. Annapurna, he collected some ammonites near Muktinath, which were brought to Kyushu University for a palaeontologic study. The collection was not great but a half of it has been donated to Tribhuvan University and the other half to Kyushu University.

The Muktinath area is celebrated for the occurrence of ammonites since the beginning of the Himalayan expedition in the nineteenth century. Recently HELMSTAEDT (1969) reported an ammonite fauna from this area, with a historical review of the study. The faunule represented by the present collection would be an addition to the hitherto described faunas and we report the result of our study in this paper.

Acknowledgements.-We would like to express our sincere thanks to the staff of the Department of Geology, Tribhuvan University and that of the Department of Mines and Geology, Nepal for kind help with valuable suggestions. We

Manuscript received July 11, 1983.

* Professor Emeritus, Kyushu University 33, Fukuoka 812. 
are grateful to Professor K. KANMERA for stimulating discussions. Photographs in the plates of this paper were made with the expert help of Dr. Masayuki NodA. Thanks are extended to Drs. I. HaYami, I. Obata, T. Kotaka and K. ARITA for their help to let us read some references kept at the libraries of the University of Tokyo, National Science Museum, Tohoku University and Hokkaido University. Miss Kazuko HarA kindly assisted us in preparing the typescript.

\section{Geological Setting}

As to the geology of the Muktinath area there are reports of HAGEN (1959, 1968) and BORDET et al. (1971). As a result of previous investigations the Nepal Himalayas are subdivided geologically into four major belts (Fig. 1). They are from north to south (1) Tethys sediments, (2) Himalayan Gneiss, (3) Midland metasediments and (4) Siwaliks.

The ammonites described in this paper came from the black shale belonging to the Spiti Shales in the first belt. The locality of the fossils is on the slope south side of the valley of the Jhong, at altitude of about $3600 \mathrm{~m}, 3 \mathrm{~km} \mathrm{NWW}$ of Muktinath. In a temple of Muktinath the hydrocarbon gas is coming out along a fault in the Spiti Shales. The shale contains nodules of various sizes in which ammonites, belemnites and others are embedded. The nodules are also

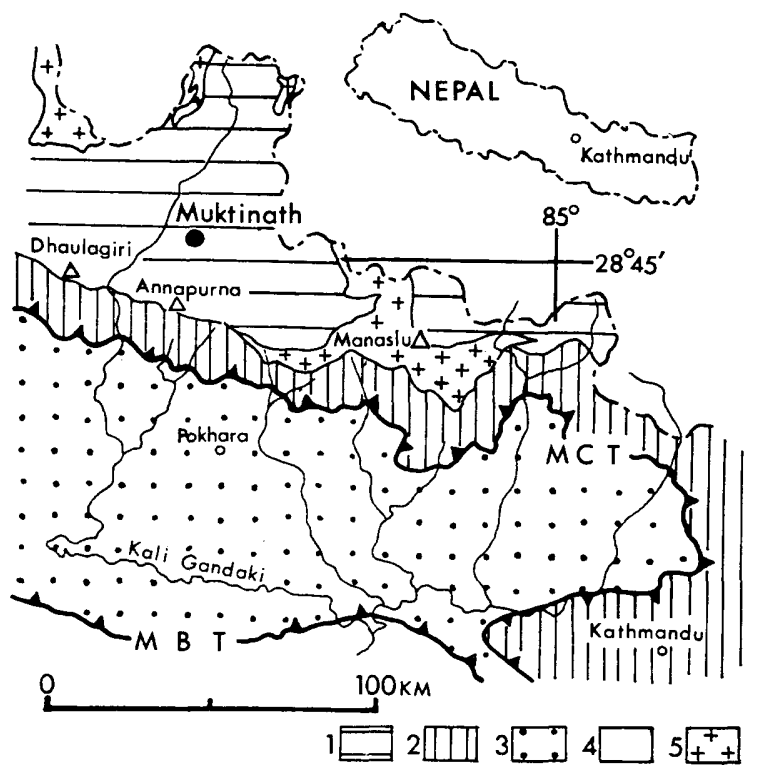

Fig. 1. Geological outline of the main part of Nepal.

1: Tethys sediments, 2: Himalayan Gneiss and Kathmandu Complex, 3: Midland metasediments, 4: Siwaliks and Quaternary. 5: Tourmaline Granite; MBT: Main Boundary Fault, MCT: Maint Central Thrust.

[compiled by SAKAI from various sources] 


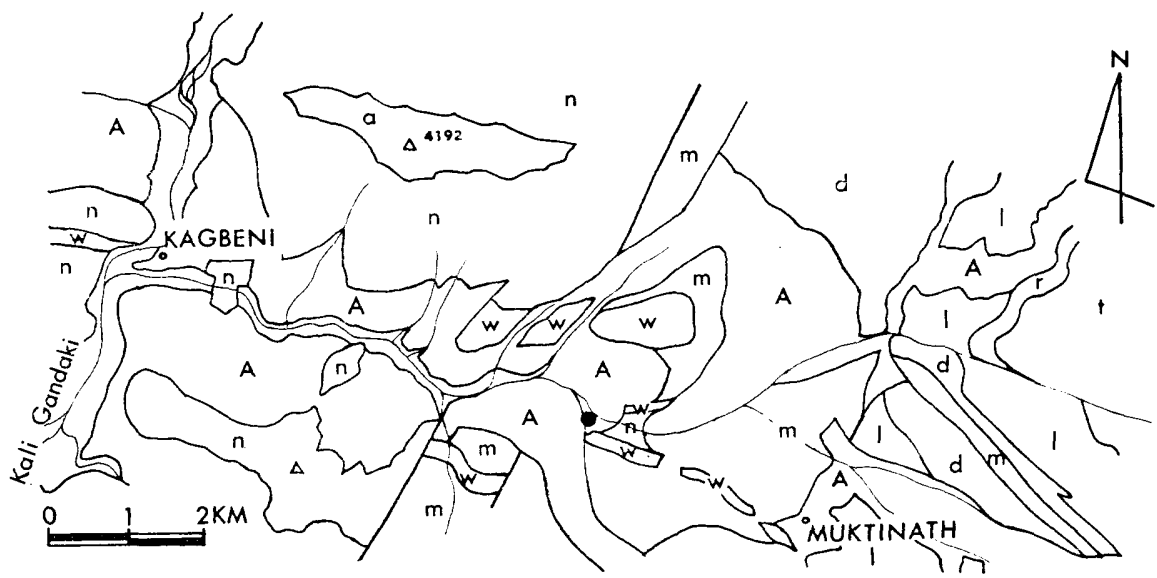

Fig. 2. Geological map of the Muktinath area. A: Alluvium and glacial sediments, a: Upper Aptian, n: Neocomian-Lower Aptian, w: Wealden, $m$ : Upper Jurassic, d: Middle Jurassic, 1: Lower Jurassic, r: Rhaetian, $t$ : Triassic. 0 : fossil locality of the described ammonites.

black colored and often disseminated with pyrite, suggesting that the shale may have been deposited under some stagnant waters. The ammonites reported in this paper are from this kind of nodules which came out from the shale exposed on a cliff for about $100 \mathrm{~m}$ in distance. The Spiti Shales are folded and faulted and outcrop in several separate places at Muktinath and its vicinities (Fig. 2).

\section{Palaeontologic Descriptions}

In this part the ammonites donated to Kyushu University are described. Their register number has the prefix GK, that is Geological Collections, Kyushu University.

Dimensions are written with abbreviations as follows: $D=$ entire shell diameter, $\mathrm{U}=$ width of umbilicus, $\mathrm{H}=$ whorl-height, $\mathrm{B}=$ whorl-breadth. Measurements are in $\mathrm{mm}$.

There is debate about the systematics of Jurassic Ammonoidea. In this paper we follow the tentative scheme proposed by DoNovan et al. (1981).

Subclass Ammonoidea ZITTEL, 1884

Order Ammonitida HyatT, 1889

Superfamily Perisphinctaceae SteinmanN, 1890

Family Aspidoceratidae ZItTEL, 1895

Subfamily Aspidoceratinae ZITTEL, 1895

Genus Aspidoceras ZitTel, 1868

Type species.-Ammonites regoznicensis ZEUSCHNER, 1846 (in ZITTEL, 1868, p. 117 , pl. 24, figs. 4-5). 
Remarks.-For the clear definition of Aspidoceras, see SPATH (1931), who separated from it Euaspidoceras SPATH, 1931, with type species Ammonites perarmatus J. SOWERBY, 1833.

\section{Aspidoceras andinum STEUER, 1921}

Pl. 7, Fig. 1

1921. Aspidoceras andinum SteUER, p. 99, pl. 5, figs. 5-7.

Material.-GK. G 11427, half of the complete shell, with body-chamber for about $160^{\circ}$ and the preceding final part of septate whorl; inner whorls poorly preserved.

\section{Dimensions.-}

\begin{tabular}{lrcccl} 
Specimen & D & U & H & B & B/H \\
GK. G 11427 & 124.0 & $39.5(.32)$ & $51.0(.41)$ & $64.4(.52)$ & 1.2 \\
Holotype (text) & 94.0 & $35.0(.37)$ & $35.0(.37)$ & $48.0(.37)$ & 1.37 \\
\multicolumn{1}{l}{ (fig.) } & 94.0 & $32.0(.34)$ & $38.0(.40)$ & $48.0(.51)$ & 1.26
\end{tabular}

Description.- Shell of moderate size, moderately involute with umbilicus of moderate width and depth. Whorl broader than high, subcircular in section, with inflated flanks and rounded venter. Umbilical shoulder abruptly rounded.

Two rows of tubercles, one at the umbilical shoulder and the other at about the middle of the flank, normally one by one disposition of tubercles between the two rows, but occasionally two of the outer row correspond to one of the inner row. Tubercles fairly distant, 5-6 per half whorl, rounded to subelliptical at the base. Faint ribs may connect the two tubercles and may be diverged on the outer part. In addition to them, finer and weaker riblets may be discernible on the ventral part, which otherwise is nearly smooth.

Partly preserved suture shows moderately incised, massive saddle between $\mathbf{E}$ and $\mathrm{L}$ and narrower trifid $\mathrm{L}$.

Comparison.-This specimen closely resembles the holotype of $A$. andinum STEuer, 1921 (p. 99, pl. 5, figs. 5-7). The dimensions in STEUER's paper seem to have been partly misprinted and those measured on the figure are indicated above, which show a close similarity to ours in shell-form. A minor difference in the number and disposition of inner and outer rows of tubercles is here interpreted as a variation.

In $A$. bussierei Collignon, 1959 (pl. 129, fig. 483), from the Kimmeridgian of Madagascar, the disposition of one inner to two outer tubercles occurs more frequently and it is characterized by more inflated broader whorl (with $\mathrm{B} / \mathrm{H}=$ 1.44) and much larger tubercles.

Occurrence.-3 km NWW of Muktinath.

\section{Explanation of Plate 7}

Fig. 1. Aspidoceras andinum SteUer .............................. 78 GK. G 11427, two lateral (a, b), ventral (c) and sectional (d) views. Scale bar $=20 \mathrm{~mm}$. 

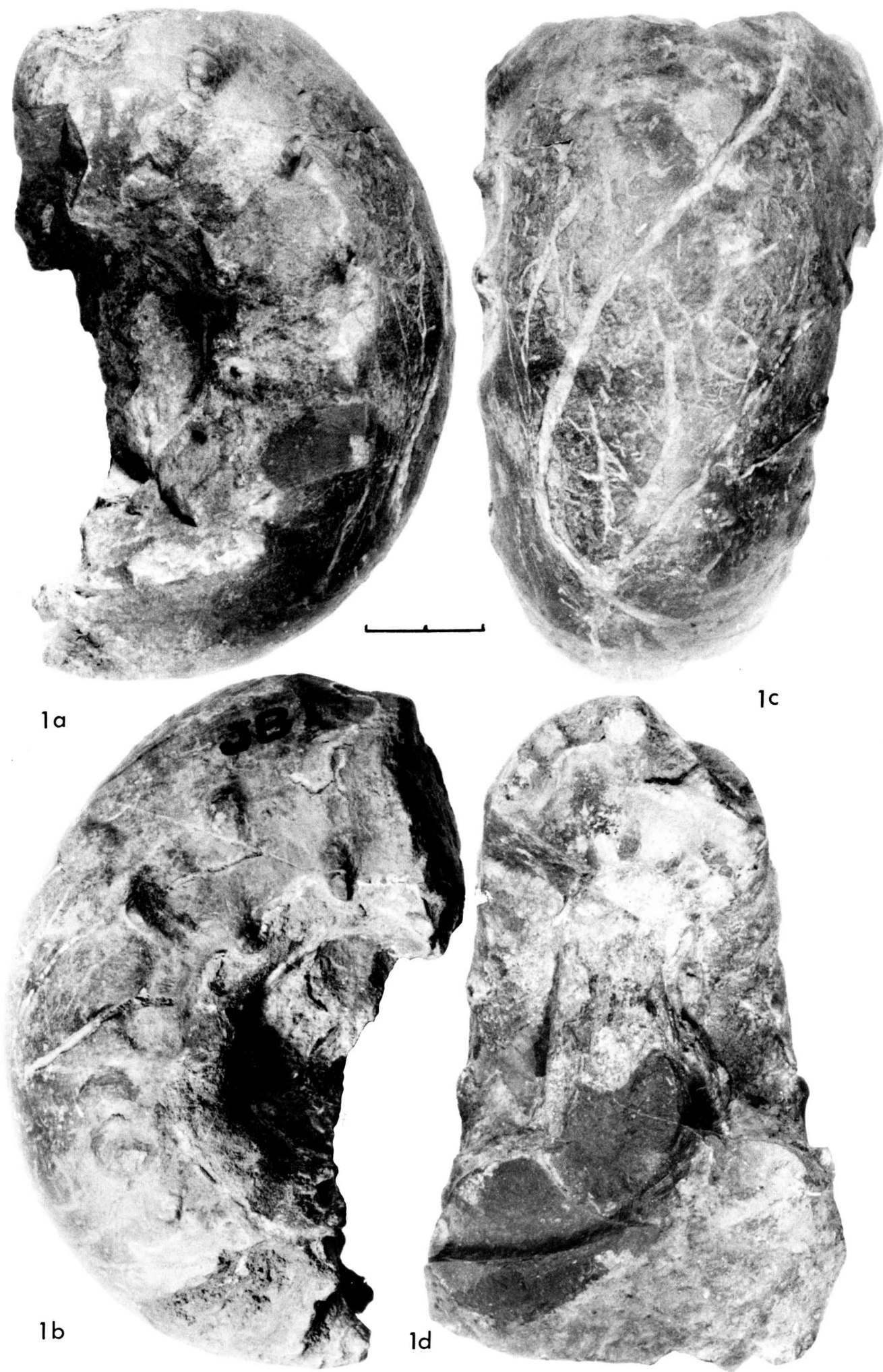

T. Matsumoto \& H. SaKai: Jurassic Ammonites 


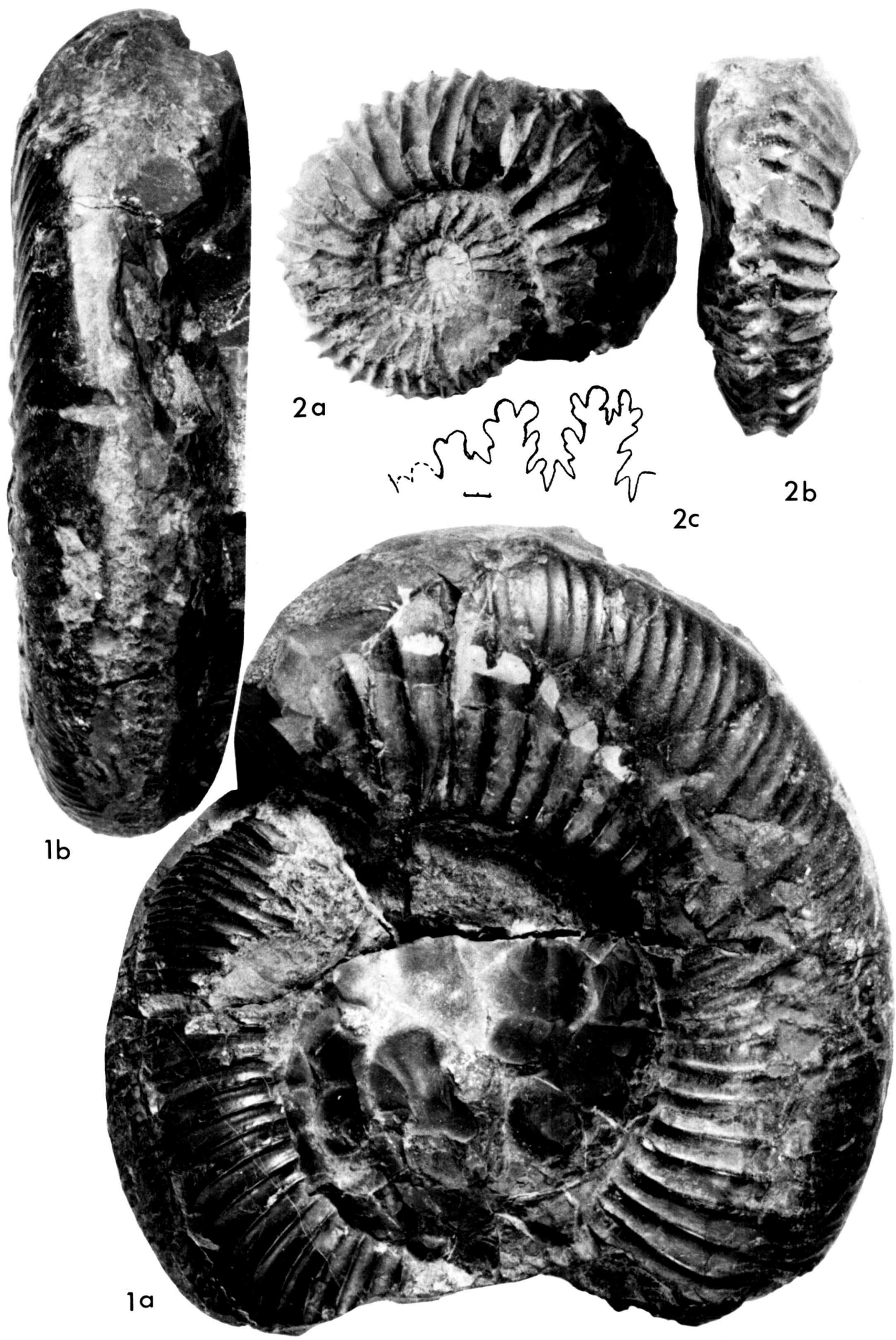

T. Matsumoto \& H. Sakai: Jurassic Ammonites 
Family Himalayitidae SPATH, 1925

Genus Corongoceras SPATH, 1925

Type species.—C. lotenoense SPATH, 1925: pro Hoplites köllikeri HaUPT, 1907 (non OPPEL).

\section{Corongoceras lotenoense SPATH, 1925}

Pl. 8, Fig. 2

1907. Hoplites köllikeri (OPPEL) ; HAUPT, p. 201, pl. 9, figs. 7a-c; 7d, e.

1925. Corongoceras lotenoense SPATh, p. 144.

1980. Corongoceras lotenoense Spath; Leanza, p. 45, pl. 6, fig. 6; text-fig. 10c.

Material.-GK. G 11428, consisting of the phragmocone and about a half whorl of the body-chamber.

\section{Dimensions.-}

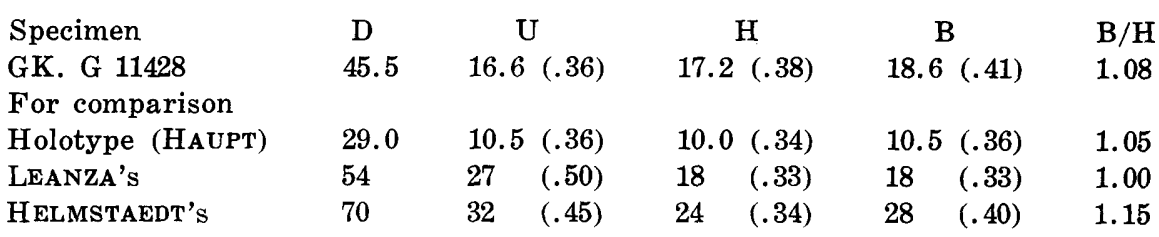

Description.-Shell small and evolute, with moderate rate of whorl expansion and moderately wide umbilicus. Whorl nearly as high as broad or somewhat broader than high, subcircular in intercostal section and polygonal in costal section.

Radial ribs strong, sharp-headed, separated by somewhat wider intervals, normally bifurcated at the tubercles on the middle of flank. Another row of tubercles on either side of the ventral groove, where ribs terminate with opposite disposition.

Suture moderately incised, with trifid L and bifid saddle between $\mathbf{E}$ and $\mathrm{L}$.

Comparison.-This specimen closely resembles the holotype of $C$. lotenoense SPATH, 1925 [=Hoplites köllikeri of HAUPT, 1907 (non OPPEL), p. 201, pl. 9, figs. $7 \mathrm{a}-\mathrm{c} ; 7 \mathrm{~d}, \mathrm{e}]$, from the Tithonian of Argentina, and is identified to the same species.

The specimen recently described under the same species by LEANZA (1980, p. 45 , pl. 6, fig. 6 ; text-fig. 10c), from the upper part of the Middle Tithonian of Neuquen, Argentina, is also similar to this specimen, but it has a wider

\section{Explanation of Plate 8}

Fig. 1. Virgatosphinctes aberrans sp. nov. .............. Page 81

GK. G 11429, lateral (a) and ventral (b) views, $\times 1$.

Fig. 2. Corongoceras lotenoense $\mathbf{S p a t h} \ldots \ldots \ldots \ldots \ldots \ldots \ldots \ldots \ldots$. . . . . . 79

GK. G 11428, lateral (a) and ventral (b) views, $\times 1$; external suture (c), $\times 2$ (bar $=2 \mathrm{~mm}$ ). 
umbilicus. There may be variation in the degree of involution and the width of umbilicus.

The specimens described under Corongoceras aff. lotenoense SpATH by HelmstaedT (1969, p. 78) could be of identical species. The umbilicus measured by him shows intermediate values of $\mathrm{U} / \mathrm{D}(0.39,0.45)$. According to him the value of $\mathrm{B} / \mathrm{H}$ increases in the late growth-stage. This cannot be examined in our specimen, because the body-chamber is somewhat distorted. Regretably HEL MSTAEDT omitted illustration.

C. loetonense (sic) var. fortior Collignon (1960, pl. 167, fig. 687), from the Upper Tithonian of Madagascar, has a narrower umbilicus and more numerous and denser ribs which are somewhat prorsiradiate. We agree with LEANZA (1980, p. 46) in regarding that specimen as distinct from C. lotenoense.

Occurrence. $-3 \mathrm{~km}$ NWW of Muktinath.

Family Ataxioceratidae BUCKMAN, 1921

Subfamily Virgatosphinctinae SPAтH, 1923

Genus Virgatosphinctes UHLIG, 1910

Type species.-Perisphinctes (Virgatosphinctes) broilii UHLIG, 1910 (sub-

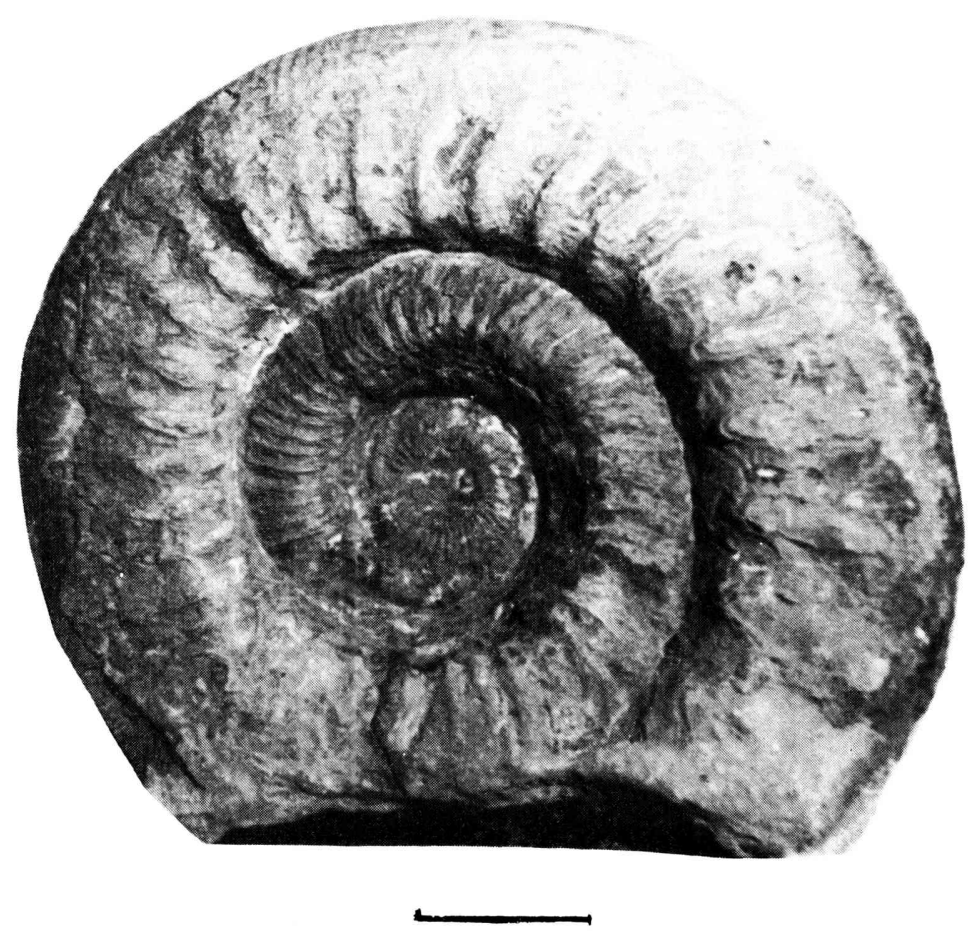

Fig. 3. Virgatosphinctes sp. aff. V. broilii (UHLIG). Lateral view of a large specimen $(\mathrm{D}=306 \mathrm{~mm})$ from a locality $3 \mathrm{~km}$ NWW of Muktinath, now kept in the Geological Collections, Tribhuvan University. Scale bar= $50 \mathrm{~mm}$.

[photo by H. SAKAI] 
sequent designation by R. DOUVILLÉ, 1910, p. 737).

Remarks.-UhLIG $(1910$, p. 307$)$ proposed Virgatosphinctes as a subgenus of Perisphinctes. The "virgatotomous" branching of primary ribs into several secondary ribs on the ventral part in late growth-stages is one of the diagnostic characters. He subdivided Virgatosphinctes into two subgroups, one with primary ribs of normal intensity represented by $V$. denseplicatus (WAAGEN, 1875) etc. and the other with stronger and more distant primary ribs on outer whorl represented by $V$. frequens (OPPEL, 1863) and several species established by himself. The type species designated by R. DouviLLÉ (1910, p. 737), p. 737), p. $(V$.$) broilii UHLIG, 1910$ is an example of the second subgroup. UHLIG himself noted, however, that there is no sharp distinction between the two subgroups and that the species of Virgatosphinctes are fairly variable.

In the present collection there are examples of the two subgroups. One is the new species of the $V$. denseplicatum subgroup and the other is also a possibly new species of the $V$. broilii subgroup. The latter is much larger $(D=306 \mathrm{~mm})$, more evolute and more widely umbilicate ( $\mathrm{U}=49 \%$ of $\mathrm{D}$ ) than $V$. broilii. It is kept in the Geological Collections, Tribhuvan University and illustrated in this paper Fig. 3) without full description.

Similarity of Virgatosphinctes to Subplanites SPATH, 1925 is noted by LEANZA (1980, p. 28), who also gives criteria to distinguish them.

\section{Virgatosphinctes aberrans sp. nov.}

Pl. 8, Fig. 1

Material.-Holotype, GK. G 11429, posterior part of body-chamber and the preceeding part of septate whorl. Paratype in the Geological Collections of Tribhuvan University.

\section{Dimensions.-}

$\begin{array}{lccccc}\text { Specimen } & \mathrm{D} & \mathrm{U} & \mathrm{H} & \mathrm{B} & \mathrm{B} / \mathrm{H} \\ \text { GK. G 11492 } & 138.5 & 61.0(.44) & 49.5(.36) & 36.0(.26) & 0.73 \\ \text { V. denseplicatum for comparison } & & & & \\ \text { Lectotype (SPATH, 1931) } & 137.0 & 60.3(.44) & 43.8(.32) & 42.5(.31) & 0.97 \\ \text { UHLIG (1910, pl.56, f.1) } & 92.5 & 32.0(.36) & 34.0(.37) & 30.5(.33) & 0.90\end{array}$

Description.-Shell discoidal, fairly large (in the restored state), with moderate rate of expansion. Whorl higher than broad, with rather narrowly arched venter. Flanks gently convex on phragmocone; flattened and subparallel on body-chamber, whose $\mathrm{B} / \mathrm{H}=\mathbf{0 . 7 3}$. Umbilicus moderately wide, about $44 \%$ of $D$, surrounded by steep but low wall and abruptly rounded shoulder.

Radial ribs somewhat prorsiradiate and gently concave on flank, passing to moderate projection on venter. On the flattened flank of body-chamber they tend to be straightened with decreasing curvature but their ventral projection is kept.

Primary ribs of moderate intensity; rather narrow, separated by somewhat wider interspaces, numbering 27 in a half whorl. Up to the middle growth-stage the primary ribs bifurcate at about the mid-flank into finer and weaker secondary 
ribs. Then intercalated ribs are added. Thus, in the late part of phragmocone and body-chamber, the secondary ribs on the ventral part are about 2.5 times as numerous as the primary ribs on the inner half of flank.

Comparison.-This species is somewhat allied to the form which was described under Virgatosphinctes denseplicatus (WAAGEN) by UHLIG (1910a, p. 313, pl. 53, fig. 3 ; pl. 54, fig. 1 ; pl. 55, figs. $1-3$; pl. 56, fig. 1 ), from the middle part of the Spiti Shales. Especially the specimen of his pl. 56, fig. 1 is similar to ours in that the body-chamber has somewhat flattened flanks and straightened, prorsiradiate ribs. Yet, our form is still more compressed (see dimensions) and has less crowded, less numerous ribs which show characteristic ventral projection. It represents a new species which is distinct from but allied to UHLIG's form.

Incidentally SPATH (1931, p. 532) designated WAAGEN's (1875, pl. 55, fig. 1) specimen from Kutch [Cutch] as the lectotype of $V$. denseplicatus and reported a considerable extent of variation in that species from the Umia Bed of Kutch, but SPATH did not seem to regard UHLIG's form from the Spti Shales as identical with $V$. denseplicatus from Kutch. $V$. aberrans differs by its own diagnosis from any variety of $V$. denseplicatus described by SPATH (1931, p. 532, pl. 77, fig. 3 ; pl. 90 , fig. 1 ; pl. 96, fig. 3 ; pl. 102, fig. 4).

Collignon (1960, pl. 154, figs. 617, 618; pl. 155, fig. 621) reported examples of $V$. denseplicatus from the Tithonian of Madagascar, from which $V$. aberrans is distinguished by its more compressed whorl and less crowded, ventrally projected ribs.

$V$. frequens (OPPEL, 1863) (p. 295, pl. 87), from the Spiti Shales of Tibet $\left(32^{\circ} 4^{\prime} \mathrm{N}, 78^{\circ} 6^{\prime} \mathrm{E}\right)$, should be brought into comparision with $V$. aberrans. The same species was redescribed by UHLIG (1910a, p. 325, pl. 63, figs. 1-3; pl. 75, fig. 1 ; pl. 75A, fig. 1) from the Spiti Shales of other localities and reported also by Collignon (1960, pl. 154, figs. 619, 620) from the Upper Tithonian of Madagascar. In this species the primary ribs tend to run somewhat obliquely forward with concave curvature on the outer whorl. This feature is similar to that in $V$. aberrans, but the primary ribs are strengthened, becoming more distant and multipartite, with more secondary ribs in the late growth-stage of $V$. frequens. In $V$. frequens the ribs are not so distinctly projected as in $V$. aberrans and the whorl is somewhat broader, with larger value of $\mathrm{B} / \mathrm{H}$.

$V$. rousseli CollignoN, 1960 (pl. 158, fig. 630), from the Upper Tithonian of Madagascar is somewhat similar to $V$. aberrans in its relatively compressed whorl (with $\mathrm{B} / \mathrm{H}=0.84$ ) and flat flanks, but it has wider umbilicus ( $49 \%$ of $\mathrm{D}$ ), with slower expansion of whorl, and subtrigonal whorl-section. In $V$. aberrans the projection of ribs on the venter appears in much earlier growth-stage than in $V$. rousseli.

Occurrence. $-3 \mathrm{~km}$ NWW of Muktinath.

\section{Genus Grayiceras Spath, 1924}

Type species.-Grayiceras blanfordi SPath, 1924 [=Ammonites nepaulensis of BLANFORD (1865) (non GRAY)]. 
Remarks.-The systematic position of this genus is still unsettled. As ARKELL (1957, p. L 298) mentioned, SPATH (1925) once proposed the family Grayiceratidae for Grayiceras, but later (SPATH, 1928) assigned it to the Mayaitidae of the Stephanocerataceae, regarding Prograyiceras of the same family as its ancestor. There is, however, a time gap between Grayiceras (of the Tithonian) and other genera of the Mayaitidae (of the Oxfordian). We follow Donovan et al. (1981), who refer Grayiceras to the Virgatosphinctinae, though with a query.

It is interesting to find an example of Grayiceras in the present collection together with other Tithonian ammonites.

Grayiceras blanfordi Spath, 1924

\section{Pl. 9, Fig. 1}

1865. Ammonites nepaulensis GraY; Blanford, pl. 14, fig. 1.

1910. Simbirskites nepaulensis (GRAY); UHLIG, p. 271, pl. 45A, fig. 1.

1924. Grayiceras blanfordi Spath, p. 11.

Material.-GK. G 11430, fairly well preserved specimen consisting both of phragmocone and body-chamber.

\section{Dimensions.-}

$\begin{array}{lccccc}\text { Specimen } & \mathrm{D} & \mathrm{U} & \mathrm{H} & \mathrm{B} & \mathrm{B} / \mathrm{H} \\ \text { GK. G 11430 } & 139.0(1) & 32.0(.23) & 61.5(.44) & 45.0(.32) & 0.73 \\ \text { BLANFORD's } & 121.0(1) & 29.0(.24) & 55.0(.45) & 48.0(.40) & 0.87\end{array}$

Description.-Shell moderately large, fairly involute, about $5 / 7$ of inner whorl being covered by outer one. Umbilicus fairly narrow, surrounded by steep wall and abruptly rounded shoulder. Whorl expanding with moderate rate, higher than broad, broadest in its lower part, subovoid in section, with gently convex and convergent flanks and narrowly arched venter.

Radial ribs numerous, consisting of primaries and secondaries. Primary ribs moderately strong, separated by somewhat wider interspaces, rursiradiate on umbilical wall, curved at umbilical shoulder, and somewhat prorsiradiate on inner half of flank. At about the middle of flank the primaries are normally bifurcated into and also intercalated by weaker and finer secondary ribs, which cross the venter with projection. Within a half whorl of body-chamber there are 13 primary ribs on the inner half of flank and 35 secondary ribs on the ventral half. Ribs on septate part of whorl denser and more numerous than those on body-chamber.

Suture fairly finely and deeply incised, but not completely traceable.

Comparison.-This specimen closely resembles the one which was described by UHLIG (1910, p. 271, pl. 45A, fig. 1) under Simbirskites nepaulensis (GRAY) from the Spiti Shales. The former is somewhat more compressed with a smaller value of $\mathrm{B} / \mathrm{H}$ and has less numerous ribs than the latter, but the difference is not great and can be regarded as variation between individuals or change with growth within one and the same species.

On the ground of the original specimens kept at British Museum (Natural History), SPATH (1924, p. 11) briefly pointed out that BlaNFORD's (1865) speci- 
men of Ammonites nepaulensis, refigured by UHLIG (1910a, pl. 45A, fig. 1) is not identical with GraY's and that it is unrelated to Simbirskites. Therefore, Spath gave it a new name, Grayiceras blanfordi SPATH, designating it as the type species of Grayiceras. SPATH assigned its age to the Tithonian.

Incidentally, the specimens from Kutch, described under Stephanoceras nepalense (GRAY) by WAAGEN (1875, p. 136, pl. 35, figs. 2, 3) were revised by SPATH (1928) to Prograyiceras grayi SPATh, which is of Oxfordian age.

Occurrence. $-3 \mathrm{~km}$ NWW of Muktinath.

\section{Family Neocomitidae SALfELd, 1921 \\ Subfamily Berriasellinae Spath, 1922 \\ Genus Paraboliceras Uhlig, 1910}

Type species.-Ammonites jubar BLANFORD, 1865 (subsequent designation by ROMAN, 1938).

Remarks.-UhLIG (1910a, p. 283) established Paraboliceras and described a number of species from the Spiti Shales under Perisphinctes (Paraboliceras), but did not designate the type species. Paraboliceras jubar (Blanford), the first species in UHLIG's description, was subsequently designated by RoMAN (1938, p. 327) as the type species. Paraboliceras is closely allied to Berriasella UHLIG, 1905, but for the parabolic ribs and nodes, and is here referred to the Berriasellinae.

\section{Paraboliceras fascicostatum (UHLIG, 1910) \\ Pl. 10, Fig. 2}

1910. Perisphinctes (Paraboliceras) fascicostatus Uhlig, p. 304, pl. 45A, fig. 2.

Material.-GK. G11431. The left side and the venter are well shown, but the right side is hardly cleaned out. The main part of the phragmocone and about $150^{\circ}$ of the body-chamber are preserved.

\section{Dimensions.-}

$\begin{array}{lrcccc}\text { Specimen } & \mathrm{D} & \mathrm{U} & \mathrm{H} & \mathrm{B} & \mathrm{B} / \mathrm{H} \\ \text { GK. G 11431 } & 102.5 & 36.7(.36) & 39.0(.38) & 28.0(.27) & 0.72 \\ \text { Holotype* } & 77.0 & 22.8(.30) & 33.0(.43) & 23.0(.30) & 0.70 \\ \text { P. haugi* } & 100.0 & 35.0(.35) & 42.0(.42) & 28.0(.28) & 0.67 \\ \text { P. himalayanum a* } & 83.0 & 27.8(.33) & 34.2(.41) & 22.5(.27) & 0.66 \\ \text { P. himalayanum b* } & 107.0 & 30.0(.28) & 46.3(.43) & 31.5(.29) & 0.68 \\ \quad \text { * After UHLIG, } & \text { 1910. } & & & & \end{array}$

Description.--Shell of medium size, about $100 \mathrm{~mm}$ in diameter, discoidal, with moderate rate of whorl expansion. About $1 / 3$ of the inner whorl over-

\section{Explanation of Plate 9}

Fig. 1. Grayiceras blanfordi Spath .................................. 83 GK. G 11430, lateral (a), ventral (b) and frontal (c) views, $\times 1$. 

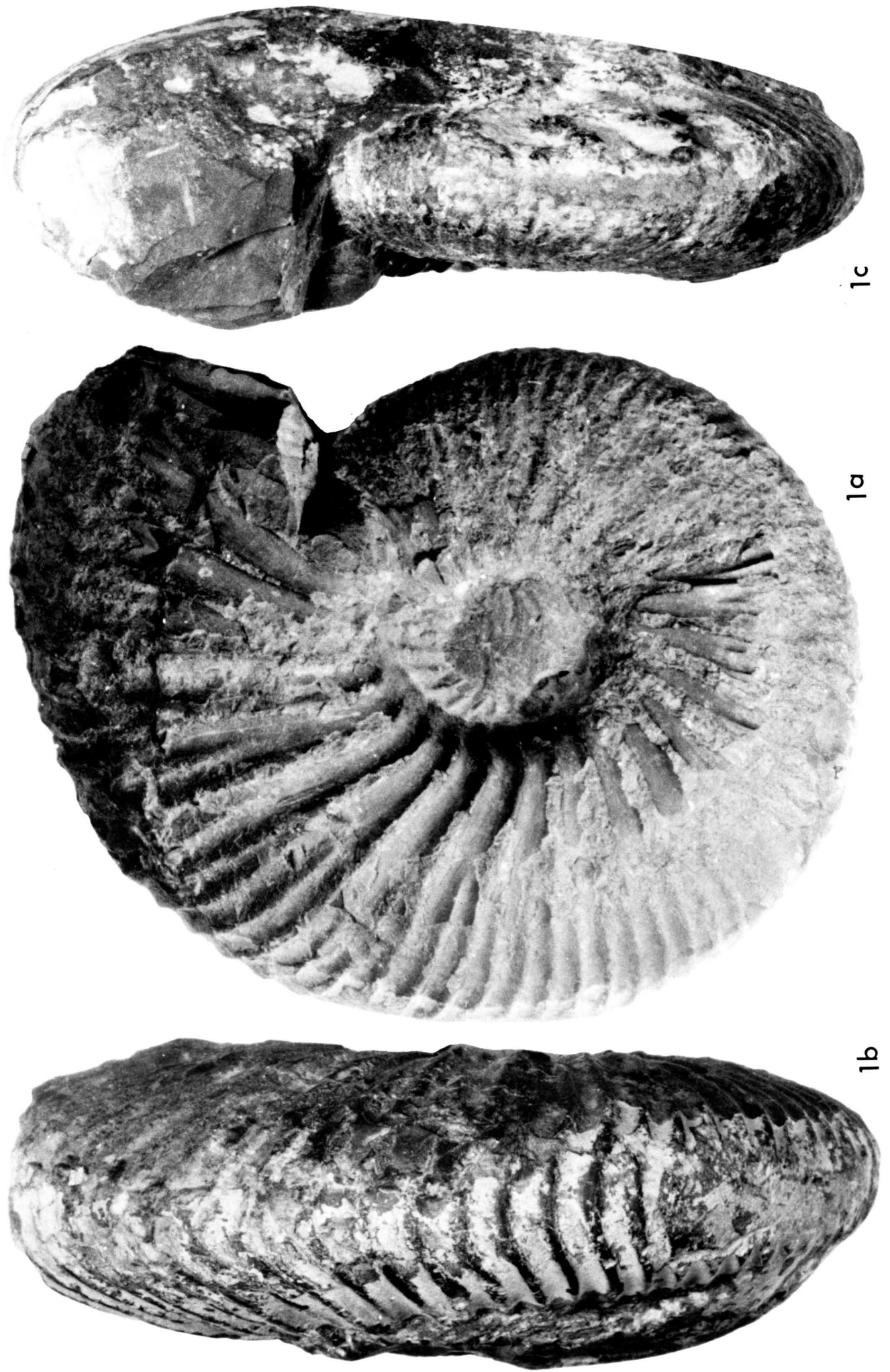

T. Matsumoto \& H. SaKaI: Jurassic Ammonites 

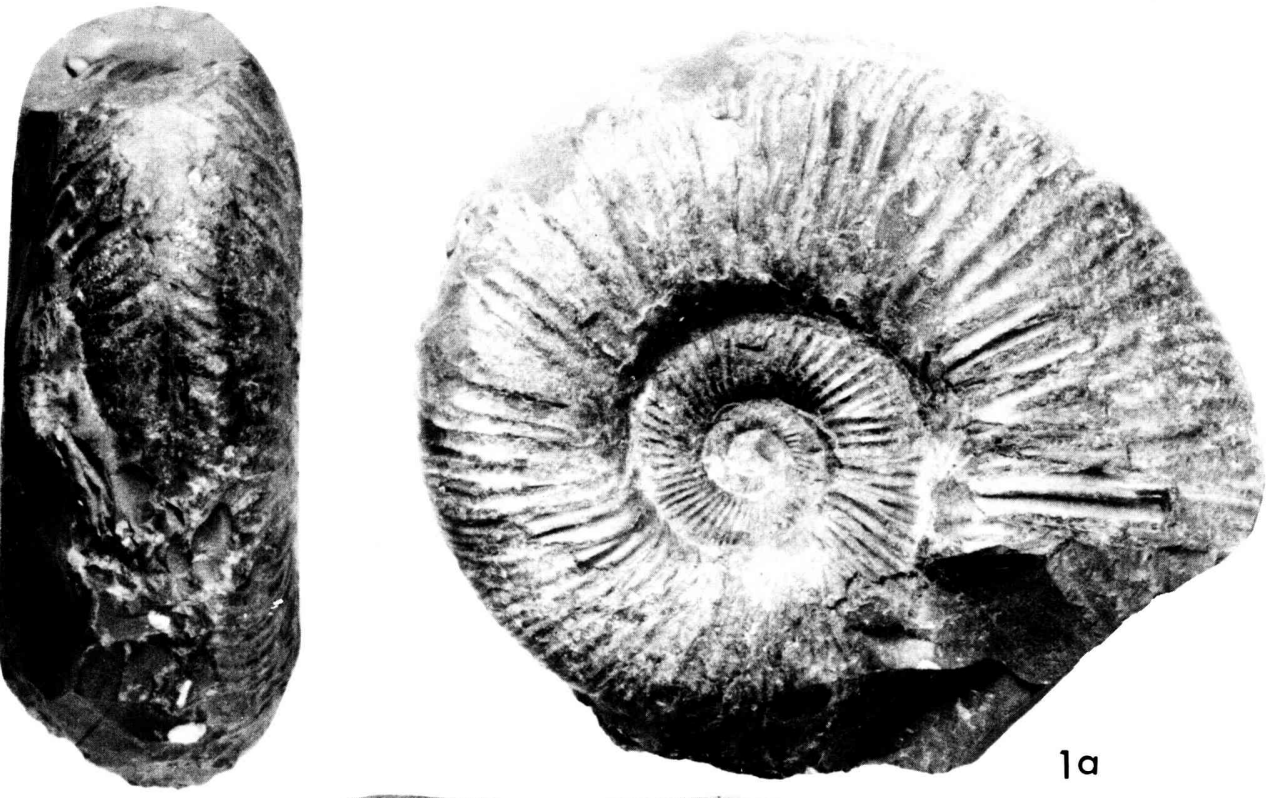

$1 b$
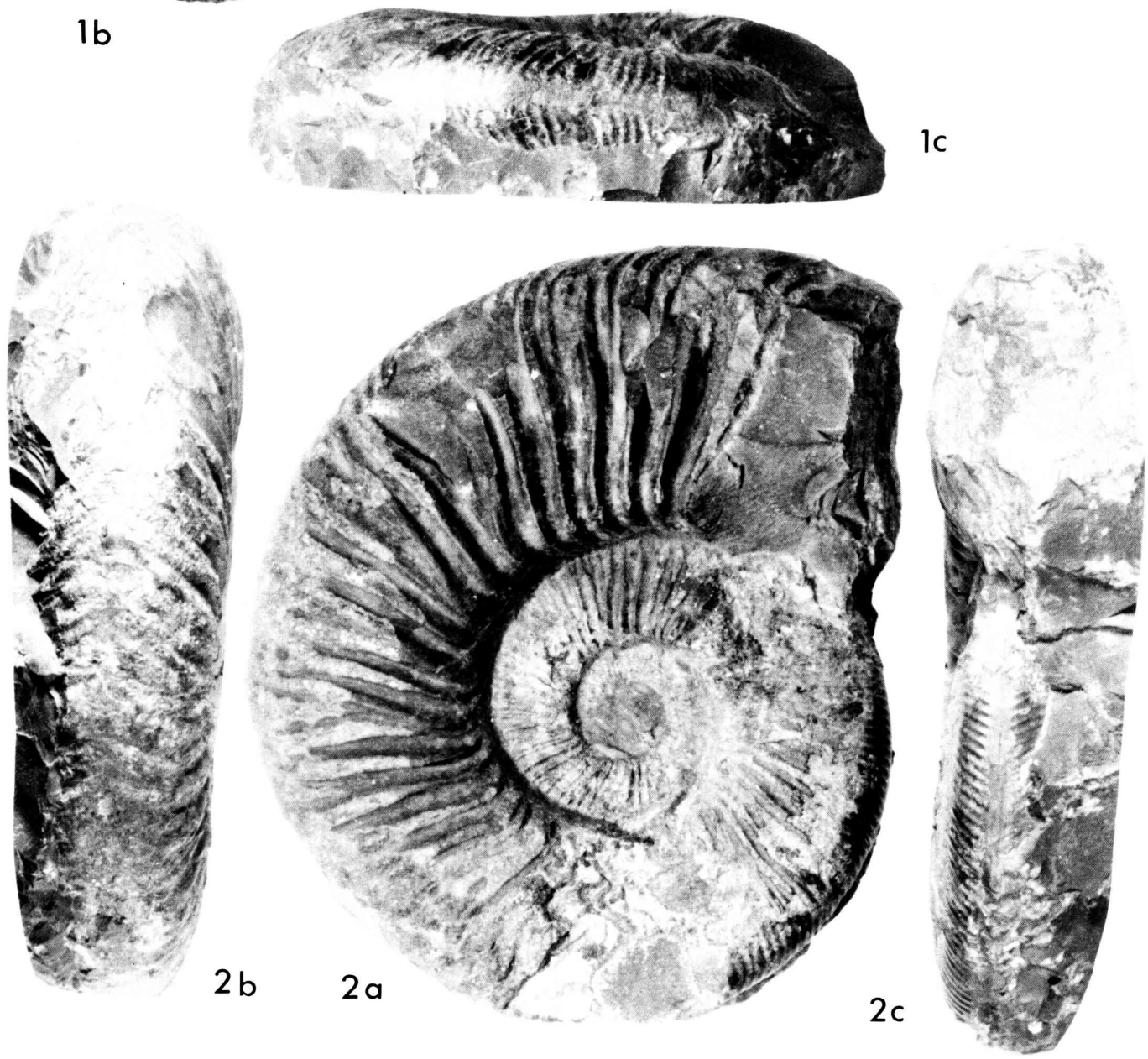

T. Matsumoto \& H. Sakai: Jurassic Ammonites 
lapped by the outer whorl. Umbilicus moderately wide, with steep but low wall. Whorl higher than broad, parallel sided in the septate stage and subelliptical in section with gently convex flanks in the adult body-chamber.

Ribs numerous, branched or intercalated outward, showing change with growth, narrow and fairly crowded on phragmocone, becoming fairly coarse on body-chamber. They arise at the umbilical margin, rursiradiate for a short distance on umbilical wall, curved (and strengthened on body-chamber) at umbilical shoulder, somewhat prorsiradiate with gentle flexuosity on flank, projected moderately on venter. In the main growth-stages the ribs terminate on either side of a narrow smooth zone along the siphonal line, but on the adoral part of the body-chamber they form chevrons. Bifurcation takes places rather irregularly at different positions on the flank; some ribs bifurcate at some distance above umbilical shoulder, some others at about mid-flank and still others on the ventrolateral part. A few ribs bifurcate twice at different point. Intercalation of shorter ribs may occur instead of or in addition to bifurcation. Hence, seemingly trichotomous feature is exhibited. On an average the secondary ribs on the venter are three times as numerous as the primary ribs on the inner half of flank.

On the posterior part of body-chamber and the preceding portion of phragmocone there are periodic pairs of nodes at the ventrolateral shoulder.

Suture finely and fairly deeply incised, with trifid L, bifid saddles on both sides of $\mathrm{L}$ and descending auxiliaries.

Comparison.- The described specimen resembles the incompletely preserved holotype of P. fascicostatum (UHLIG, 1910) (p. 304, pl. 45A, fig. 2) and shows well the diagnostic features of that species. $P$. fascicostatum is peculiar in that the parabolic nodes occur in a very limited period of growth-stage and that the ribs are seemingly trichotomous. The coarse primary ribs begin to appear at $\mathrm{D}=45 \mathrm{~mm}$ in the holotype, but at $\mathrm{D}=65 \mathrm{~mm}$, the final of phragmocone, in our specimen.

In this connexion P. haugi (Uhlig, 1910) (p. 297, pl. 44, fig. 4; pl. 48A, fig. 1) and P. himalayanum (Uhlig, 1910) (p. 296, pl. 46, fig. 1) should be brought into comparison with $P$. fascicostatum. In $P$. haugi the primary ribs are gradually strengthened with growth and in the late stage they are very coarse and separated by fairly wide interspacies. In $P$. himalayanum the primary ribs are very slowly strengthened with age and at the observable final stage they are not so much coarsened as in $P$. haugi. In this respect $P$. fascicostatum represents an intermediate state. In shell-form the three nominal species resembles one another (see dimensions), and it could be considrd that the three forms might represent varieties within one and the same species. This should be examined on

\section{Explanation of Plate 10}

Fig. 1. Paraboliceras tibeticum (UHLIG) ........................ 85 GK. G 11432, lateral (a), anterior ventral (b) and posterior ventral (c) views, $\times 1$.

Fig. 2. Paraboliceras fascicostatum (UHLIG) ................. Page 84 GK. G 11431, lateral (a), ventral (b) and frontal (c) views, $\times 1$. 
sufficiently numerous specimens. In the present state of our knowledge we identify our specimen to $P$. fascicostatum.

Occurrence. $-3 \mathrm{~km}$ NWW of Muktinath.

\section{Paraboliceras tibeticum (UHLIG, 1910)}

Pl. 10, Fig. 1

1910. Perisphinctes (Parboliceras) tibeticum UHLIG, p. 295, pl. 46, fig. 2.

Material.-GK. G 11432, phragmocone for the most part with a fraction of body-chamber at the preserved end.

\section{Dimensions.-}

$\begin{array}{lcccccc}\text { Specimen } & \text { D } & \text { U } & \text { H } & \text { B } & \text { B/H } \\ \text { GK. G 11432 } & 90.0 & 31.0(.34) & 35.8(.40) & 27.3(.30) & 0.76 \\ \text { Holotype } & 120.0 & 34.5(.29) & 56.3(.47) & 32.2(.27) & 0.57 \\ \text { P. sabinianum } & 135 & 48(\cdot 35) & 51 \quad(.37) & 35 & (.26) & 0.69\end{array}$

Description.-Shell of moderate size, with restored diameter presumably more than $120 \mathrm{~mm}$. Whorl enlarging with moderate rate and with moderate overlap. Umbilicus of moderate width, with low but steep wall. Whorl higher than broad, broadest slightly below mid-flank, with slightly convex flanks. Venter narrow and flattened on top.

Ribs numerous and narrow; in young stage up to $\mathrm{D}=30 \mathrm{~mm}$ regular, slightly prorsiradiate on the main part of flank and bifurcate on the outer part. From the middle growth-stage onward the bifurcating point is variable and some ribs are periodically stronger than others with slight elevation at the umbilical shoulder and provided with nodes on either side of the siphonal flat zone. On the main part of flank some ribs are slightly prorsiradiate with or without gentle flexuosity; others nearly rectiradiate. Thus the ribbing looks rather irregular. On the venter ribs are projected weakly. Some ribs are looped at the nodes.

Suture partly exposed, showing pattern similar to that of the preceding species.

Comparison.-This specimen is similar to the holotype of $P$. tibeticum (UhLIG, 1910) (p. 295, pl. 46, fig. 2) in the essential points, but has a somewhat wider umbilicus and a larger value of $\mathrm{B} / \mathrm{H}$ (see dimensions). In this respect, it resembles the specimens of $P$. sabinianum (OPPEL, 1863) (p. 286, pl. 82, fig. 1 only) (Uhlig, 1910a, p. 292, pl. 44, fig. 3; pl. 48, fig. 3). This kind of difference can occur between different growth-stages as well as between individuals. In fact UHLIG distinguished $P$. tibeticum from $P$. sabinianum with much hesitation and transferred one of OPPEL's (1863, pl. 82, fig. 2) specimens of Ammonites sabinianus to $P$. tibeticum. Another difference between the two species is, according to UHLIG, in the ornament. In $P$. sabinianum the periodic ribs with nodes are much stronger and more flexuous than other ribs but in $P$. tibeticum this difference is less distinct. In this respect our specimen is closer to P. tibeticum. Again, this kind of character could be variable within a species. The possibility that $P$. tibeticum could be synonimous with $P$. sabinianum still remains. Our material is not sufficient for the final conclusion. We identify our specimen 
provisionally with $P$. tibeticum.

Occurrence. $-3 \mathrm{~km}$ NWW of Muktinath.

\section{Concluding Remarks}

Taxonomic result:-The species described above are summarized in the following list:

1. Aspidoceras andinum STEUER

2. Corongoceras lotenoense SPATH

3. Virgatosphinctes aberrans MATUMoto et SAKAI, sp. nov.

4. Grayiceras blanfordi SPATH

5. Paraboliceras fascicostatum (UHLIG)

6. Paraboliceras tibeticum (UHLIG)

These are kept at the Geological Collections of Kyushu University. In addition to them the following species are identified by us and now kept at the Department of Geology, Tribhuvan University:

7. Uhligities cf. kraffti (UHLIG)

8. Kossmatia cf. desmidoptycha (UHLIG)

9. Kossmatia sp. aff. K. desmidoptycha (UHLIG)

10. Virgatosphinctes sp. nov. (?) aff. V. broilii (UHLIG)

In the above listed forms, (8) and (9) are similar to each other but have dissimilar dimensions: the former is $138 \mathrm{~mm}$ in $\mathrm{D}$, whereas the latter is $93 \mathrm{~mm}$ and has lappets and a constriction at the apertural margin. Therefore they probably represent a dimorphic pair: the macroconch (8) and the microconch (9).

In the Collections of Tribhuvan University, there are also the paratype of $V$. aberrans and several specimens of the Belemnoidea.

Correlation.-As to the stratigraphic subdivison of the Spiti Shales the investigation of DIENER (1895) at Niti, about $450 \mathrm{~km}$ northwest of Muktinath outside of Nepal, has afforded us a reference sequence. According to him the Spiti Shales are tripartite in ascending order as follows:

Lower Spiti Shales [=Belemnopsis gerardi Beds]

Middle Spiti Shales [=Chidamu Beds]

Upper Spiti Shales [=Lochambel Beds]

This scheme has been applied to the Spiti Shales in other areas, but what part of the above scheme the locality of our collection should be referred to is not determined at once.

Aside from sundry reports, UHLIG's (1903, 1910a) magnificent monograph covers most comprehensively the ammonite faunas of the Spiti Shales, with discussions on the age corrleation and palaeogeography (UHLIG, 1910b). On this ground ARKELL (1956) concluded that the Lower Spiti is Upper Oxfordian, the Middle Spiti Upper Kimmeridgian to Lower Tithonian, and the Upper Spiti Upper Tithonian to Berriasian or further to Valanginian, with a stratigraphic gap representing the Lower and Middle Kimmeridgian between the Lower Spiti and the Middle Spiti. For some reasons ARKell did not discuss whereabout of the 
Middle Tithonian in the Spiti Shales.

Ammonites derived from the Spiti Shales have long been known as Saligrams, charms for Hindu pilgrims. As Muktinath is a holyplace for the pilgrims, ammonites from the Muktinath area were occasionally reported. ARKELL (1956, p. 414) identified the Saligram ammonites in the collection of the Sedgwick Museum, which may be of several different stratigraphic levels. More recently, HELmSTAEDT (1969) described a fauna from the Muktinath area, but his locality is north of Muktinath and not the same as our locality. The localities of ammonites listed by BORDET et al. (1971) and KAMADA et al. (1982) are also different from ours.

Our collection was from one locality $3 \mathrm{~km} \mathrm{NWW}$ of Muktinath. It depended on nodules derived probably from the exposure at that locality but the possibility that some nodules might have been transported from the nearby exposures cannot be ruled out.

Of the ten ammonite species in our collection (listed above), six (listed under $4,5,6,7,8,9)$ are referred to the species which have already been described by UHLIG (1910a). For some reason their stratigraphic positions were not precisely pin-pointed by UHLIG. Grayiceras blanfordi, for example, is based on a specimen of an old collection reported by BLANFORD (1865) and devoid of reliable stratigraphic records. There was a debate as to its systematic position and geologic age. SPATH (1923) regarded its age as Tithonian, whereas ARKELL (1957) preferred an Oxfordian age. It is interesting to find an example of this species in our collection which is generally of a Tithonian faunule. Paraboliceras fascicostatum and $P$. tibeticum were established on the specimens of a poor stratigraphic record, but the genus Paraboliceras is closely related to Beriasella and generally considered as comparatively later parts of the Tithonian in age.

Uhligites kraffti, a species of the Oppeliidae, and Kossmatia desmidoptycha were recorded by UHLIG as "Middle and Upper Spiti". This is an ambiguous expression as if the range is from the Middle Spiti to the Upper Spiti. It could mean also that the so-called Middle Spiti at one locality might be synchronous with a part of the so-called Upper Spiti at another locality.

In the ammonite fauna from the north of Muktinath, HELMSTAEDT (1969) listed (but not described) Kossmatia aff. desmidoptycha, Paraboliceras cf. sabineanum, $P$. cf. haugi, and $P$. aff. fascicostatum, among many others. According to him the majority of that fauna is of Upper Tithonian age, because of the predominance of Blanfordiceras and the presence of several species which suggest the Barriasian.

Anyhow, in the faunule of our collection there is no species which belong to Spiticeras, Himalayites, Blanfordiceras and Berriasella. These genera characterize the Upper Spiti, probably the uppermost Tithonian and Berriasian.

On the other hand, there are several species which are identical with the species from the Middle Tithonian of Argentina, where the Upper Jurassic to Lower Cretaceous sequences are more precisely subdivided on bistratigraphic grounds. For instance, according to LEANZA (1980), Aspidoceras andinum occurs in the Zone of Aulacosphinctes proximus, middle Middle Tithonian, and Corongo- 
ceras lotenoense in the next higher Zone of Windhauseniceras internispinosum, upper Middle Tithonian of Argentina.

Virgatosphinctes aberrans is a new species and may not be useful for the age correlation. It has some peculiar characters and deviates from typical representatives of Virgatosphinctes, such as V. denseplicatum and V. broilii. It is somewhat allied to $V$. rousseli from the Upper Tithonian of Madagascar. Incidentally CoLlignoN (1960) bipartites the Tithonian in Madagascar, without using the Middle Tithonian.

Another species provisionally called $V$. sp. aff. $V$. broilii is distinct from $V$. broilii in its more widely umbilicate, larger shell. In the upper part of Lower Tithonian LEANZA (1980) listed several species of Virgatosphinctes in which there is an evolute form, $V$. evolutus LEANZA. HELMSTAEDT (1969), however, listed several species of the same genus and also Subplanites in his 'mainly Upper Tithonian' fauna north of Muktinath.

To sum up the above discussions, the faunule represented by our collection from the locality $3 \mathrm{~km} \mathrm{NWW}$ of Muktinath is of Tithonian age and probably correlated to the Middle Tithonian, although we reserve the possibility that a few elements of the upper Lower Tithonian and/or those of the lower Upper Tithonian could have intermingled in the collection. Our collection is a product of a geological reconnaissance. Through this study we have noticed that it is utterly needed to establish a precise scheme of biostratigraphic zonation for the Spiti Shales in some suitable places.

Palaeogeography.-The Spiti Shales in the Himalayas have been regarded as a part of the Tethys sediments and the ammonites and other fossils from them have been called the Tethyan fauna. However, in the light of modern earthsciences, the meaning of the Tethys has changed much from the concept at the date of Uhlig (1910b) and ARKell (1956), although the original proposal of SuEss could be extended or modified in any way.

The Tethys in the original sense was an ocean, but the Spiti Shale, along with the underlying limestone and overlying sandstone (quartz arenite), are by no means the sediments of oceanic depths. They must have deposited in a shallow sea basin on the marginal part of the continental basement facing the true ocean Tethys. What then was that continent? In view of the facts that the plant fossils of the elements of the Gondwana flora occurred in a part of the so-called Tethys sediments (GANSSER, 1964; YIN and GUo, 1978; ARITA, 1981), the continent must have been the Gondwana Land.

If we follow the reconstructed palaeogeographic map of BARRoN et al. (1981, map at 140 million years), the late Jurasic ammonite localities of Nepal, Kutch and Madagascar were fairly close to one another and roughly in the same latitude (about $45^{\circ} \pm 5^{\circ} \mathrm{S}$ ) on the marginal shelf of the Gondwana Land facing the oceanic Eastern Tethys (Fig. 4). In the same map a transgressive seaway was extended from west of Madagascar to the southern part of the Andes, and the Tithonian ammonite localities in Argentina were not much separated from those of Madagascar and Kutch. In fact LEANZA (1980) has concluded that the Tithonian fauna of Argentina shows close affinities with those of Madagascar and India as well as Mexico. 


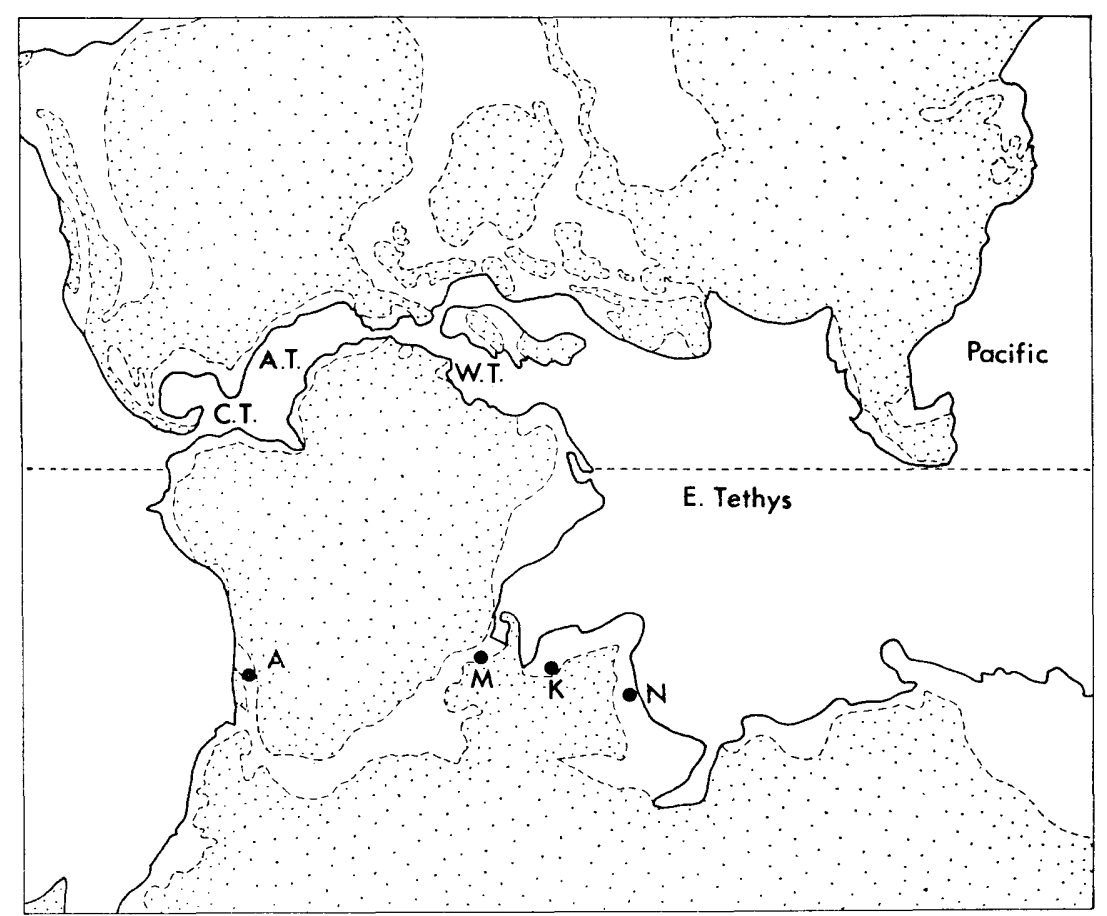

Fig. 4. Palaeogeographic map of the Tithonian age. A.T.: Atlantic Tethys, C.T.: Caribbean Tethys, W.T.: Western Tethys. - Locations of the discussed faunas, A: Neuquen in Argentina, $\mathrm{K}$ : Kutch in India, M: Madagascar, N : Muktinath in Nepal.

[Palaeogeographic reconstruction adapted from BARRON et al., 1981 with permission of the Society]

The above discussion is a thought from our study on a fraction of the Spiti. This would be extended and improved by analysing more comprehensively the fauna of the Spiti Shales as well as by sedimentological study of the so-called Tethys sediments.

\section{References Cited}

ARITA, K. (1981): Geology of the Himalayas, with special reference to the Nepal Himalayas. Recent Progress Nat. Sci. Japan, 6, 76-83.

ARKELl, W. J. (1956): Jurassic Geology of the World. Oliver \& Boyd, Edinburgh, 806 p., 46 pls.

(1957): In Moone, R. C. (ed.): Treatise on Invertebrate Paleontology, Part L, L232-L362.

Barron, E. J., Harrison, Ch. G. A., Slloan II, J. L. and Hay, W. W. (1981) : Paleogeography, 180 million years ago to the present. Eclogae Geol. Helv., 74, 443470 , pls. $1-9$.

Blanford, H. F. (1865) : In SAlter, J. W. and Blanford, H. F.: Palaeontology of Niti in the Northern Himalaya, Calcutta (inaccessible).

Bordet, P., Colchen, M., Krummenacher, D., Le Fort, P., Mounterde, R. and Remy, M. (1971): Recherches Géologiques dans l'Himalaya du Nepal, region de la Thakkola. Centr. Nat. Rech. Sci., Paris, 279 p., map. 
Collignon, M. (1959): Atlas des Fossiles Caracteristiques de Madagascar, 5 (Kimmeridgien), pls. 96-133, Serv. Géol. Tananarive.

(1960): Ditto, 6 (Tithonien), pls. 134-175, Serv. Géol. Tananarive.

Diener, C. (1895): Ergebnisse einer geologische Expedition in den Zentral-Himalaya von Johar, Hundes und Painkhanda. Denkschr. Akad. Wiss. Wien (Math.Naturw. Cl.), 57, 533-607, pls. 1-7.

Donovan, D. T., Callomon, J. H. and Howarth, M. K. (1981) : Classification of the Jurassic Ammonitina. In House, M. R. and SENIOR, J. R. (eds.): The Ammonoidea. Syst. Assoc. Spec. Vol., 18, 101-155.

Douvillé, R. (1910): Un Virgatites du Causase occidental; origine méditerraneenne de ce genre; Ataxioceras, Pseudovirgatites et Virgatosphinctes. Bull Soc. Géol. France, sér. 4, 10 (4), 730-739.

GaNsSER, A. (1964): Geology of the Himalayas. Wiley-Interscience, London, $289 \mathrm{p}$.

HAGEN, T. (1959) : Geologie des Thakkholas (Nepal). Eclogae Geol. Helv., 52, 709-719. (1968): Report of the geological survey of Nepal. 2-Geology of Thakkhola, including adjacent areas. Mem. Soc. Helv. Sc. Nat., 86, $160 \mathrm{p}$.

Haupt, O. (1907): Beiträge zur Fauna des oberen Malm und der unteren Kreide in den argentinischen Cordillere. Neues Jahrb. Min. Geol. Beil. Bd., 23, 187-236, pls. $7-10$.

HelmstaedT, H. (1969) : Eine Ammoniten Fauna aus den Spitischiefern von Muktinath in Nepal. Zitteliana, 1, 63-88, pls. 3-5.

Kamada, K., Arita, K. and Yoshida, M. (1982): Jurassic ammonites from the Muktinath region, central Himalaya. Jour. Nepal Geol. Soc., 2, special issue, 149-155.

Leanza, H. A. (1980): The Lower and Middle Tithonian ammonite fauna from Cerro Lotena, Province of Neuquen, Argentina. Zitteliana, 5, 3-49, pls. 1-9.

OPPEL, A. (1863): Ueber ostindische Fossilreste aus den secundären Ablagerungen von Spiti und Gnari-Khorsu in Tibet. Palaeont. Mitt. Mus. k. Bayer. Staates, 4, 267-302, pls. $75-82$.

Roman, F. (1938): Les Ammonites Jurassiques et Cretacées. Mason, Paris, 554 p., 53 pls.

Spath, L. F. (1924): On the Blake collection of ammonites from Kachh, India. Mem. Geol. Surv. India, Palaeont. Indica, N. S., 9, (1), 1-29.

(1925): Ammonites and aptychi. In B. N. K. Wyllie \& W. E. SMellie (ed.) : The collection of fossils and rocks from Somaliland. Hunt. Mus. Glasgow Univ., Monograph, 7, 111-164, pls. 15-16.

(1927-33): Revision of the Jurassic cephalopod fauna of Kachh (Cutch). Ibid., N. S., 9, (2), pt. 1-6, 945 p., 130 pls.

Steuer, A. (1921): Estratos jurácicos argentions. Actas Acad. Nac. Cienc. Cordoba, 7, 33-128, pls. 1-24.

Uhlig, V. (1903-1910a): Fauna of the Spiti Shales. Mem. Geol. Surv. India, Palaeont. Indica, ser. 15, Himalayan Fossils, 4, 1-132, pls. 1-18 (1903) ; 133-395, pls. 19-93 (1910).

- $(1910 \mathrm{~b})$ : Die Fauna der Spiti-Schiefer des Himalayas, ihr geologisches Alter und ihre Weltstellung. Denkschr. Akad. Wiss. Wien (Math.-Naturw. Cl.), 85, 531-609.

WAAGEN, W. (1873-1875): Jurassic fauna of Kutch. The Cephalopoda. Mem. Geol. Surv. India, Palaeont. Indica, ser. 9, 1, 247 p., 58 pls.

YIN Ji-xiang and Guo Shi-zeng (1978): Mt. Qomolangma and the beds at its northern slope. Scientia Sinica, 21 (5), 629-644.

Zittel, K. A. von (1868): Die Cephalopoden der Stramberger Schichten. Paläont. Mitt. Mus. k. Bayer. Staates, 2 (1), 33-118, pls. 1-24. 